\title{
$\alpha$-Melanocyte-Stimulating Hormone Is Contained in Nerve Terminals Innervating Thyrotropin-Releasing Hormone-Synthesizing Neurons in the Hypothalamic Paraventricular Nucleus and Prevents Fasting-Induced Suppression of Prothyrotropin-Releasing Hormone Gene Expression
}

\author{
Csaba Fekete,, ${ }^{1,2}$ Gábor Légrádi, ${ }^{1}$ Emese Mihály, ${ }^{1}$ Qin-Heng Huang, ${ }^{1}$ Jeffrey B. Tatro, ${ }^{1}$ William M. Rand, ${ }^{3}$ \\ Charles H. Emerson, ${ }^{4}$ and Ronald M. Lechan ${ }^{1,5}$ \\ 1 Tupper Research Institute and Department of Medicine, Division of Endocrinology, Diabetes, Metabolism, and Molecular \\ Medicine, New England Medical Center, Boston, Massachusetts 02111, 2Department of Neurobiology, Institute of \\ Experimental Medicine, Hungarian Academy of Sciences, Budapest, Hungary 1083, ${ }^{3}$ Department of Community Health, \\ Tufts University School of Medicine, Boston, Massachusetts 02111, "4Department of Medicine, Division of Endocrinology, \\ University of Massachusetts Medical School, Worcester, Massachusetts 01655, and 5 Department of Neuroscience, Tufts \\ University School of Medicine, Boston, Massachusetts 02111
}

The hypothalamic arcuate nucleus has an essential role in mediating the homeostatic responses of the thyroid axis to fasting by altering the sensitivity of prothyrotropin-releasing hormone (pro-TRH) gene expression in the paraventricular nucleus (PVN) to feedback regulation by thyroid hormone. Because agouti-related protein (AGRP), a leptin-regulated, arcuate nucleus-derived peptide with $\alpha$-MSH antagonist activity, is contained in axon terminals that terminate on TRH neurons in the PVN, we raised the possibility that $\alpha$-MSH may also participate in the mechanism by which leptin influences pro-TRH gene expression. By double-labeling immunocytochemistry, $\alpha$-MSH-IR axon varicosities were juxtaposed to $\sim 70 \%$ of pro$\mathrm{TRH}$ neurons in the anterior and periventricular parvocellular subdivisions of the PVN and to $34 \%$ of pro-TRH neurons in the medial parvocellular subdivision, establishing synaptic contacts both on the cell soma and dendrites. All pro-TRH neurons receiving contacts by $\alpha$-MSH-containing fibers also were innervated by axons containing AGRP. The intracerebroventricular infusion of $300 \mathrm{ng}$ of $\alpha$-MSH every $6 \mathrm{hr}$ for $3 \mathrm{~d}$ prevented fasting-induced suppression of pro-TRH in the PVN but had no effect on AGRP mRNA in the arcuate nucleus. $\alpha$-MSH also increased circulating levels of free thyroxine (T4) 2.5-fold over the levels in fasted controls, but free T4 did not reach the levels in fed controls. These data suggest that $\alpha$-MSH has an important role in the activation of pro-TRH gene expression in hypophysiotropic neurons via either a mono- and/or multisynaptic pathway to the PVN, but factors in addition to $\alpha-\mathrm{MSH}$ also contribute to the mechanism by which leptin administration restores thyroid hormone levels to normal in fasted animals.

Key words: thyrotropin-releasing hormone; thyroid axis; $\alpha-\mathrm{MSH}$; arcuate nucleus; fasting; agouti-related protein; leptin
The biosynthesis and secretion of thyrotropin-releasing hormone (TRH) in hypophysiotropic neurons of the paraventricular nucleus (PVN) are regulated by a negative feedback control mechanism that depends on circulating levels of thyroid hormone (Koller et al., 1987; Segerson et al., 1987; Kakucska et al., 1992). During fasting, however, when thyroid hormone levels fall, a seemingly paradoxical reduction in hypophysiotropic TRH and an inappropriately normal or low plasma thyrotropin (TSH) are observed, consistent with central hypothyroidism (Rondeel et al., 1992; van Haasteren et al., 1995; Legradi et al., 1997). These alterations can be completely reversed by the systemic administration of leptin to fasting animals (Legradi et al., 1997), leading us to propose that the arcuate nucleus, a major locus for the central actions of leptin (Hakansson et al., 1996; Huang et al.,

\footnotetext{
Received Aug. 2, 1999; revised Sept. 27, 1999; accepted Oct. 15, 1999.

This work was supported by National Institutes of Health Grant DK-37021. We appreciate the expert technical assistance of Marta Powell and Scott Stone.

Correspondence should be addressed to Dr. Ronald M. Lechan, Professor of Medicine, Division of Endocrinology, Box Number 268, New England Medical Center, 750 Washington Street, Boston, MA 02111. E-mail address: rlechan@ lifespan.org.

Copyright (C) 2000 Society for Neuroscience $\quad 0270-6474 / 00 / 201550-09 \$ 15.00 / 0$
}

1996; Mercer et al., 1996; Schwartz et al., 1996), can reset the sensitivity of hypophysiotropic neurons to the feedback effects of thyroid hormone (Legradi et al., 1998). In support of this hypothesis, ablation of the arcuate nucleus abolishes the effect of fasting and leptin administration to fasting animals on pro-TRH gene expression in the PVN (Legradi et al., 1998). Potential inhibitory regulators of TRH that mediate the effect of fasting are neuropeptide Y (NPY) and agouti-related protein (AGRP), both contained within a monosynaptic pathway originating from arcuate nucleus neurons and terminating on TRH neurons in the PVN (Legradi and Lechan, 1998, 1999). Because AGRP is believed to exert its biological activity by antagonizing melanocortin receptors (Ollmann et al., 1997), its mRNA is regulated inversely to pro-opiomelanocortin (POMC) mRNA by fasting and leptin administration (Schwartz et al., 1997; Mizuno et al., 1998; Mizuno and Mobbs, 1999), and interaction between AGRP and $\alpha$-MSH, the latter a cleavage product of POMC, is involved in the regulation of body weight (Fan et al., 1997; Rossi et al., 1998), we questioned whether $\alpha$-MSH may also be involved in the regulation of the hypothalamic-pituitary-thyroid axis as a stimulatory factor. In this study, therefore, we determined whether axons 
containing $\alpha$-MSH establish morphological relationships with TRH-producing neurons in the PVN and whether the intracerebroventricular administration of synthetic $\alpha$-MSH to fasting animals is capable of restoring pro-TRH mRNA levels in hypophysiotropic neurons toward normal.

\section{MATERIALS AND METHODS}

Animals. The experiments were performed on adult male Sprague Dawley rats (Taconic, Germantown, NY), weighing 210-230 gm. The animals were housed individually in cages under standard environmental conditions (light between 0600 and $1800 \mathrm{hr}$; temperature, $22 \pm 1{ }^{\circ} \mathrm{C}$; rat chow and water available ad libitum). All experimental protocols were reviewed and approved by the Animal Welfare Committee at the New England Medical Center and Tufts University School of Medicine.

Tissue preparation for immunocytochemistry. Eight animals were deeply anesthetized with sodium pentobarbital $(50 \mathrm{mg} / \mathrm{kg}$ of body weight, i.p.) and stereotaxically injected intracerebroventricularly with $60 \mu \mathrm{g}$ of colchicine in $6 \mu \mathrm{l}$ of $0.9 \%$ saline. After $20 \mathrm{hr}$ of survival, the animals were perfused transcardially with $20 \mathrm{ml}$ of $0.01 \mathrm{M}$ PBS, $\mathrm{pH} 7.4$, containing $15,000 \mathrm{U} / 1$ heparin sulfate, followed sequentially by $100 \mathrm{ml}$ of $2 \%$ paraformaldehyde and $4 \%$ acrolein in $0.1 \mathrm{M}$ phosphate buffer (PB), $\mathrm{pH}$ 7.4 , and $30 \mathrm{ml}$ of $2 \%$ paraformaldehyde in the same buffer. The brains were rapidly removed and stored in PBS for $24 \mathrm{hr}$ at $4^{\circ} \mathrm{C}$. Serial $25-\mu \mathrm{m}$ thick coronal sections were cut with a vibratome and collected in PBS. The sections were treated for 30 min with $1 \%$ sodium borohydride in distilled water for light microscopy or with $1 \%$ sodium borohydride in 0.05 м PB for electron microscopy, followed by $0.5 \% \mathrm{H}_{2} \mathrm{O}_{2}$ in PBS for 15 min. Light microscopic sections were permeabilized with $0.5 \%$ Triton $\mathrm{X}-100$ in PBS overnight at $4^{\circ} \mathrm{C}$. To reduce the nonspecific antibody binding, the sections for both light and electron microscopy were treated with $2.5 \%$ normal horse serum in PBS for 20 min.

Light microscopic double-labeling immunocytochemistry of $\alpha$-MSH-IR axons and pro-TRH-IR elements in the PVN. Every third tissue section through the PVN was incubated for $2 \mathrm{~d}$ at $4^{\circ} \mathrm{C}$ in sheep anti- $\alpha$-MSH antiserum, raised in our laboratory, and used at a titer of 1:150,000, diluted in PBS containing 2.5\% normal horse serum, 0.2\% Kodak PhotoFlo (Eastman Kodak, Rochester, NY), and 0.2\% sodium azide. Specificity of the immunolabeling with this antiserum has been reported elsewhere (Elias et al., 1998b). After rinses in PBS, the sections were incubated in biotinylated donkey anti-sheep IgG for $3 \mathrm{hr}$ (1:500; Jackson ImmunoResearch, West Grove, PA) followed by the avidin-biotinperoxidase complex (ABC Elite; 1:100; Vector Laboratories, Burlingame, CA) in PBS for $2 \mathrm{hr}$ at room temperature. The immunoreaction product was developed with $0.05 \%$ diaminobenzidine (DAB), $0.15 \%$ nickel ammonium sulfate $(\mathrm{Ni})$, and $0.005 \% \mathrm{H}_{2} \mathrm{O}_{2}$ in $0.05 \mathrm{M}$ Tris buffer, pH. 7.6 (TB), and intensified using a modification of the Gallyas silver intensification technique to yield a black precipitate (Liposits et al., 1986), but without thioglycolic acid treatment.

After visualization of $\alpha$-MSH, the sections were incubated for $2 \mathrm{~d}$ at $4^{\circ} \mathrm{C}$ in a rabbit antiserum recognizing prepro-TRH $178-199$ (a gift of Dr. E. Redei, Northwestern University, Chicago, IL) diluted 1:25,000. This antiserum has been characterized by Nillni (2000) and shown by electrophoretic separation of immunoprecipitated radiolabeled peptides from rat hypothalamic neurons in culture to recognize a $2.6 \mathrm{kDa}$ peptide characteristic of prepro-TRH 178-199. After washing in PBS, the tissue sections were incubated in donkey anti-rabbit IgG (1:500; Jackson ImmunoResearch) and the ABC Elite complex (1:100). The immunolabeling was visualized by $0.025 \% \mathrm{DAB}$ and $0.0036 \% \mathrm{H}_{2} \mathrm{O}_{2}$ in $\mathrm{TB}$, alone, to yield a brown reaction product. Thus, the black, silver-intensified NiDAB labeled $\alpha$-MSH fibers, and the brown, DAB-labeled pro-TRH-IR elements could be easily distinguished in the same sections.

Light microscopic triple-labeling immunofluorescence of $\alpha$-MSH- and AGRP-IR fibers and pro-TRH-IR elements in the PVN. To determine whether pro-TRH-producing neurons in the PVN receive dual innervation by axon terminals containing $\alpha$-MSH and AGRP, we visualized the three antigens with three distinct fluorochromes by fluorescence immunocytochemistry. In the first step, after the pretreatment described above, tissue sections containing the PVN were incubated in a mixture of sheep anti- $\alpha$-MSH (1:7500) and rabbit anti-AGRP (1:3000; Phoenix Pharmaceuticals, Mountain View, CA) for $4 \mathrm{~d}$ at $4^{\circ} \mathrm{C}$. The sections were rinsed in PBS and then incubated in a mixture of Texas Red-conjugated donkey anti-sheep IgG (1:50; Jackson ImmunoResearch) and biotinylated donkey anti-rabbit $\operatorname{IgG}(1: 200)$ for $2 \mathrm{~d}$ at $4^{\circ} \mathrm{C}$, followed by further washes and incubation in avidin-FITC DCS (1:250; Vector Laboratories) for $2 \mathrm{~d}$ at $4^{\circ} \mathrm{C}$. The tissues were then incubated in rabbit anti-preproTRH 178-199 (1:5000) for $4 \mathrm{~d}$ at $4^{\circ} \mathrm{C}$, followed by incubation in 7-amino4-methylcoumarin-3-acetic acid (AMCA)-conjugated donkey anti-rabbit IgG (1:50; Jackson ImmunoResearch) for $2 \mathrm{~d}$ at $4^{\circ} \mathrm{C}$. The sections were mounted on gelatin-coated slides, coverslipped with Vectashield mounting medium (Vector Laboratories), and analyzed under a Zeiss Axioskop 2 epifluorescent microscope using the following filter sets: for Texas Red, excitation of 540-590 nm, bandpass of $595 \mathrm{~nm}$, and emission of $600-660 \mathrm{~nm}$; for FITC, excitation of 460-500 nm, bandpass of $505 \mathrm{~nm}$, and emission of 510-560 nm; and for AMCA, excitation of 320-400 nm, bandpass of $400 \mathrm{~nm}$, and emission of $430-490 \mathrm{~nm}$. Thus, $\alpha-\mathrm{MSH}-$ containing fibers were labeled in red, AGRP-containing fibers were labeled in green, and pro-TRH-containing perikarya were labeled in blue under their respective filter sets. Images were captured with a Spot digital camera (Diagnostic Instrument, Sterling Heights, MI), the same field triple exposed while switching the filter sets for each fluorochrome and superimposed using Adobe Photoshop 5.0 and a Macintosh G3 computer to create a composite image for analysis. Because AGRP-IR was labeled with FITC before the incubation with antiserum to pro-TRH, the FITC fluorochrome labeled only the AGRP-IR fibers and not the TRH-IR elements. Although AMCA-conjugated anti-rabbit IgG labeled both AGRP- and pro-TRH-IR elements, no AGRP-containing neurons are present in the PVN (Broberger et al., 1998; Legradi and Lechan, 1999). The superimposition of the yellow-green fluorescence of FITC and the blue fluorescence of AMCA in the composite images yielded a green color of the AGRP-IR fibers, which was distinct from the blue fluorescence contained in the pro-TRH-IR elements.

Double-labeling electron microscopic immunohistochemistry for $\alpha$-MSH and pro-TRH in the PVN. Sections processed for electron microscopy were incubated in sheep anti- $\alpha$-MSH antiserum $(1: 20,000)$ for $4 \mathrm{~d}$ at $4^{\circ} \mathrm{C}$, followed by biotinylated donkey anti-sheep $\operatorname{IgG}(1: 500)$ for $12 \mathrm{hr}$ at $4^{\circ} \mathrm{C}$ and the ABC Elite complex (1:100). Immunoreactivity was detected with $\mathrm{DAB}$ as described above. The sections were then placed into rabbit anti-prepro-TRH 178-199 (1:8000) for $2 \mathrm{~d}$ at $4^{\circ} \mathrm{C}$ and, after rinsing in PBS and $0.1 \%$ cold-water fish gelatin (Electron Microscopy Sciences, Fort Washington, PA) in PBS, were incubated in goat anti-rabbit IgG conjugated with $0.8 \mathrm{~nm}$ colloidal gold (Electron Microscopy Sciences) diluted at 1:100 in PBS containing 0.1\% cold-water fish gelatin. The sections were washed in the same diluent and PBS, followed by a $10 \mathrm{~min}$ treatment in $1.25 \%$ glutaraldehyde in PBS. After rinsing in $0.2 \mathrm{M}$ sodium citrate, $\mathrm{pH} 7.5$, the gold particles were silver intensified with the IntenSE Kit (Amersham, Arlington Heights, IL) (Branchereau et al., 1995). Sections were treated with $2 \%$ osmium tetroxide in $0.1 \mathrm{M}$ PB for $1 \mathrm{hr}$, dehydrated in an ascending series of ethanol followed by propylene oxide, flat embedded in Durcupan ACM epoxy resin (Fluka, Neu-Ulm, Germany) on liquid release agent (Electron Microscopy Sciences)-coated slides, and polymerized at $56^{\circ} \mathrm{C}$ for $2 \mathrm{~d}$. Ultrathin sections were cut with an MRC MT6000 ultramicrotome (MRC, Tuscon, AZ), collected onto Formvar-coated single-slot grids, and examined without heavy metal contrasting using a Phillips CM-10 electron microscope.

Animal preparation for $\alpha$-MSH infusion. To determine whether $\alpha$-MSH is capable of restoring pro-TRH mRNA levels to normal in fasting animals, we implanted adult Sprague Dawley rats with a 22 gauge stainless steel guide cannula (Plastics One, Roanoke, VA) into the lateral cerebral ventricle under stereotaxic control (coordinates from bregma, anteroposterior, -0.8 ; lateral, 1.2; and ventral, 3.2) through a burr hole in the skull. The cannula was secured to the skull with three stainless steel screws and dental cement and temporarily occluded with a dummy cannula. Bacitracin ointment was applied daily to the interface of the cement and the skin. Animals were weighed daily, and any animal showing signs of illness or weight loss was removed from the study and killed. One week after intracerebroventricular cannulation, the animals were divided into four groups. The first group $(n=9)$ had food available ad libitum and was injected intracerebroventricularly with $6 \mu \mathrm{l}$ of artificial CSF (140 mM NaCl, $3.35 \mathrm{~mm} \mathrm{KCl}, 1.15 \mathrm{~mm} \mathrm{MgCl}_{2}, 1.26 \mathrm{~mm} \mathrm{CaCl}_{2}$, $1.2 \mathrm{mM} \mathrm{Na}_{2} \mathrm{HPO}_{4}$, and $0.3 \mathrm{~mm} \mathrm{NaH} \mathrm{PO}_{4}, \mathrm{pH} 7.4$ ) containing $0.1 \%$ bovine serum albumin (BSA) every $6 \mathrm{hr}$ for the duration of the experiment. The second $(n=9)$, third $(n=4)$, and fourth $(n=8)$ groups were fasted for $64 \mathrm{hr}$ beginning at $1600 \mathrm{hr}$ on the first day and ending between 0900 and $1200 \mathrm{hr}$ on the fourth day and injected intracerebroventricularly with $6 \mu \mathrm{l}$ of artificial CSF, $150 \mathrm{ng}$ of $\alpha$-MSH (Peninsula Laboratories, Belmont, CA) in $6 \mu \mathrm{l}$ of artificial CSF, or $300 \mathrm{ng}$ of $\alpha$-MSH in $6 \mu \mathrm{l}$ of artificial CSF, respectively, every $6 \mathrm{hr}$. All intracerebroventricular injections were made in freely moving animals through a 28 gauge needle that extended $1 \mathrm{~mm}$ below the guide cannula, connected by polyethylene 
tubing to a $50 \mu \mathrm{l}$ Hamilton syringe, and was infused over 5 min by an inf usion pump (Bee Electronic Minipump; BAS, West Lafayette, IN). At completion of the experiment, the animals were anesthetized with sodium pentobarbital, blood was taken from the inferior vena cava for measurement of serum thyroxine (T4), free T4, and TSH, and the animals were immediately perfused with fixative as described below. Blood was collected into polypropylene tubes and centrifuged for $15 \mathrm{~min}$ at $4000 \mathrm{rpm}$, and the plasma was stored at $-80^{\circ} \mathrm{C}$ until assayed.

Tissue preparation for in situ hybridization histochemistry. Under sodium pentobarbital anesthesia, the animals were perfused transcardially with $20 \mathrm{ml}$ of $0.01 \mathrm{M}$ PBS, $\mathrm{pH}$ 7.4, containing 15,000 U/1 heparin sulfate, followed by $150 \mathrm{ml}$ of $4 \%$ paraformaldehyde in PBS. The brains were removed and post-fixed by immersion in the same fixative for $2 \mathrm{hr}$ at room temperature. Tissue blocks containing the hypothalamus were cryoprotected in $20 \%$ sucrose in PBS at $4^{\circ} \mathrm{C}$ overnight and then frozen on dry ice. Serial $18-\mu \mathrm{m}$-thick coronal sections through the rostrocaudal extent of the PVN and the arcuate nucleus were cut on a cryostat (Reichert-Jung 2800 Frigocut-E) and adhered to Superfrost/Plus glass slides (Fisher Scientific, Houston, TX) to obtain four sets of slides, each set containing every fourth section through the PVN and arcuate nucleus (ARC). Cannula placement was confirmed by light microscopic examination, and animals with cannulas outside the lateral ventricle were excluded from further study. The tissue sections were desiccated overnight at $42^{\circ} \mathrm{C}$ and stored at $-80^{\circ} \mathrm{C}$ until prepared for in situ hybridization histochemistry.

In situ hybridization histochemistry. Every fourth section of the PVN was hybridized with a 1241 base pair single-stranded ${ }^{35} \mathrm{~S}$-UTP-labeled cRNA probe for pro-TRH as described previously (Dyess et al., 1988; Kakucska et al., 1992). Serial sections taken from the arcuate nucleus were hybridized with a labeled 260 base pair single-stranded antisense ${ }^{35}$ S-UTP RNA probe for AGRP, generously provided by Dr. G. Barsh (Stanford University School of Medicine, Stanford, CA) and previously characterized by Ollmann et al. (1997). The hybridization was performed under plastic coverslips in a buffer containing $50 \%$ formamide, a twofold concentration of SSC $(2 \times$ SSC), $10 \%$ dextran sulfate, $0.5 \%$ SDS, 250 $\mu \mathrm{g} / \mathrm{ml}$ denatured salmon sperm DNA, and $6 \times 10^{5} \mathrm{cpm}$ of radiolabeled probe for $16 \mathrm{hr}$ at $56^{\circ} \mathrm{C}$. Slides were dipped into Kodak NTB2 autoradiography emulsion (Eastman Kodak), and the autoradiograms were developed after $2 \mathrm{~d}$ (pro-TRH) or $7 \mathrm{~d}$ (AGRP) of exposure at $4^{\circ} \mathrm{C}$. The specificity of hybridization was confirmed using sense probes that resulted in the absence of specific hybridization in the PVN and arcuate nucleus.

Image analysis. Autoradiograms were visualized at $78 \times$ under darkfield illumination using a COHU 4910 video camera (COHU, San Diego, CA). The intensity of the light source was maintained constant by conversion of AC current through a DC power supply (EPSCO, Addison, IL). The images were captured with a color PCI frame grabber board (Scion Corporation, Frederick, MD) and analyzed with a Macintosh G3 computer using Scion Image. Background density points were removed by thresholding the image, and integrated density values (density $\times$ area) of hybridized neurons in the same region of each side of the PVN or ARC were measured in six consecutive sections for each animal. Nonlinearity of the radioactivity in the emulsion was evaluated by comparing density values with a calibration curve created from autoradiograms of known dilutions of the radiolabeled probes immobilized on glass slides in $2 \%$ gelatin fixed with $4 \%$ formaldehyde and exposed and developed simultaneously with the in situ hybridization autoradiograms.

Hormone measurements. Plasma T4 and TSH concentrations were measured by RIA. Materials for the TSH RIA were provided by the National Hormone and Pituitary Program (Baltimore, MD) using the National Institute of Diabetes and Digestive and Kidney Diseases rat TSH RP-2 as the standard. Plasma T4 levels were measured with a specific RIA using antiserum from Ventrex (Portland, ME) and ${ }^{125} \mathrm{I}$ labeled T4 obtained from New England Nuclear (Boston, MA). Equilibrium dialysis was used to determine the fraction of T4 in plasma that was free. The details of the assay have been reported previously (Castro et al., 1986). The Cobra 500 program was used for data reduction and calculation of the RIA results.

Statistical analysis. The results are presented as mean \pm SEM. Statistical significance was determined by nested ANOVA, followed by the Student-Newman-Keuls multiple comparison test. Differences were considered to be significant at $p<0.05$. All statistical analyses were run using SPSS (SPSS, Chicago, IL).

\section{RESULTS}

\section{$\alpha$-MSH-IR innervation of pro-TRH-containing neurons in the PVN}

$\alpha$-MSH-IR axons heavily innervated all major parvocellular portions of the PVN, but most intensely the anterior, ventral, and periventricular parvocellular subdivisions and the most caudal portion of the medial parvocellular subdivision (Fig. $1 A-C$ ). By double-labeling light microscopic immunocytochemistry, varicose $\alpha$-MSH-IR fibers were in juxtaposition to the majority of proTRH-IR neurons in the anterior and periventricular parvocellular subdivisions of the PVN (Fig. 1D,E), whereas substantially fewer pro-TRH-IR neurons in the medial and dorsal parvocellular subdivision appeared to be contacted by $\alpha$-MSH axon varicosities (Fig. $1 F, G$ ). Cell counts from three animals showed that $\sim 70 \%$ of the pro-TRH-containing neurons were found in contact with $\alpha$-MSH axon varicosities in the anterior $(70 \pm 3.6 \%)$ and periventricular $(72 \pm 1.2 \%)$ parvocellular subdivisions of the PVN, whereas $<50 \%$ of the pro-TRH-containing neurons received contacts in the medial $(34 \pm 0.5 \%)$ and dorsal $(47 \pm 0.3 \%)$ parvocellular subdivisions.

By ultrastructural analysis of the periventricular parvocellular subdivision, DAB-labeled $\alpha$-MSH-IR terminals containing numerous small clear vesicles and some dense core vesicles were seen to establish synapses on pro-TRH neurons, the latter identified by the presence of the highly electron-dense silver particles (Fig. 2). Tracing the juxtaposed $\alpha$-MSH-IR terminals and proTRH-IR neurons through a series of ultrathin sections on the same neuron, we observed both axodendritic (Fig. $2 A$ ) and axosomatic (Fig. 2B) synaptic specializations.

\section{Dual innervation of pro-TRH-IR neurons by $\alpha$-MSH- and AGRP-IR terminals in the PVN}

By triple-labeling immunofluorescence, AGRP-IR axon varicosities were found to be juxtaposed to all pro-TRH neurons receiving $\alpha$-MSH-IR innervation (Fig. $1 H, I$ ). The majority of the double-innervated neurons were found in the anterior and periventricular subdivisions of the PVN. $\alpha$-MSH- and AGRPcontaining axon varicosities established contacts with both the perikarya and dendrites of these neurons, but the number of AGRP terminals around pro-TRH neurons was more numerous than the number of $\alpha$-MSH terminals. Several pro-TRH-IR neurons were also observed in contact with AGRP axons, alone (Fig. $1 H, I)$.

\section{Effect of fasting and $\alpha$-MSH administration to fasting animals on the body weight and plasma hormone levels}

Fasted animals lost $\sim 22 \%$ of their body weight during the experiment, whereas the fed controls gained 5\% of their body weight. Fasted animals receiving an $\alpha$-MSH intracerebroventricular infusion also showed significant weight reduction (20\%), which was not significantly different from the weight loss of the fasted control animals.

Table 1 shows the results of plasma total and free thyroid hormone and TSH determinations. Serum T4 and free T4 levels were significantly reduced in fasted animals to $\sim 20 \%$ of that in fed controls, whereas the free T4 fraction was significantly increased and TSH was inappropriately low for the concentration of thyroid hormone. Administration of $300 \mathrm{ng}$ of $\alpha$-MSH intracerebroventricularly every $6 \mathrm{hr}$ significantly attenuated the effect of fasting on thyroid hormone levels and resulted in an $\sim 2.5$-fold increase of T4 and free T4 compared with that in fasted animals 


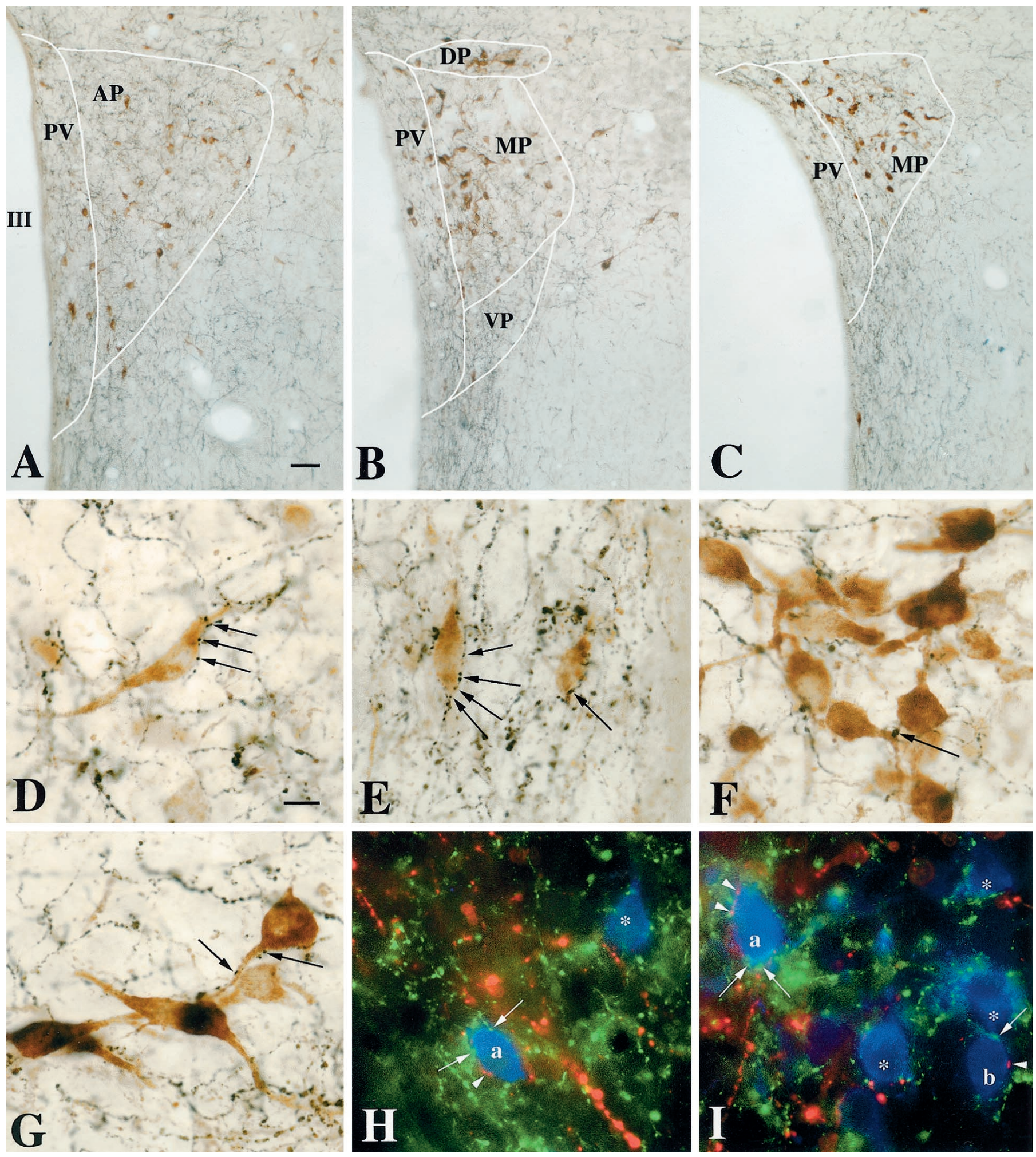

Figure 1. A-C, Low-power photomicrographs showing the distribution of $\alpha$-MSH-IR axons (black) and pro-TRH-containing neurons (brown) in different levels of the PVN. A, Anterior level of the PVN. B, Mid level of the PVN. $C$, Caudal level of the PVN. $D-G$, High-power magnification of $\alpha$-MSH-IR axon varicosities (arrows) contacting pro-TRH neurons in the anterior $(D)$, periventricular $(E)$, medial $(F)$, and dorsal $(G)$ parvocellular subdivisions of the PVN. Note that the majority of the pro-TRH-IR neurons are contacted by $\alpha$-MSH-IR fibers in the anterior and periventricular subdivisions, whereas fewer pro-TRH-IR neurons in the medial and dorsal parvocellular subdivisions appear to be innervated by $\alpha$-MSH-IR axons. $H$, I, Triple-labeling fluorescent immunocytochemistry showing dual innervation of periventricular $(a)$ and medial $(b)$ parvocellular proTRH neurons $(b l u e)$ of the PVN by axon terminals containing $\alpha$-MSH (red; arrowheads) and AGRP (green; arrows). Note that all pro-TRH-containing neurons establishing contacts with $\alpha$-MSH-IR terminals are also contacted by several AGRP-IR varicosities, whereas other pro-TRH-IR neurons (asterisks) receive only an AGRP-IR innervation. $A P$, Anterior parvocellular subdivision; $D P$, dorsal parvocellular subdivision; $M P$, medial parvocellular subdivision; $P V$, periventricular parvocellular subdivision; $V P$, ventral parvocellular subdivision. Scale bars: $A-C, 100 \mu \mathrm{m} ; D-I, 20 \mu \mathrm{m}$. 


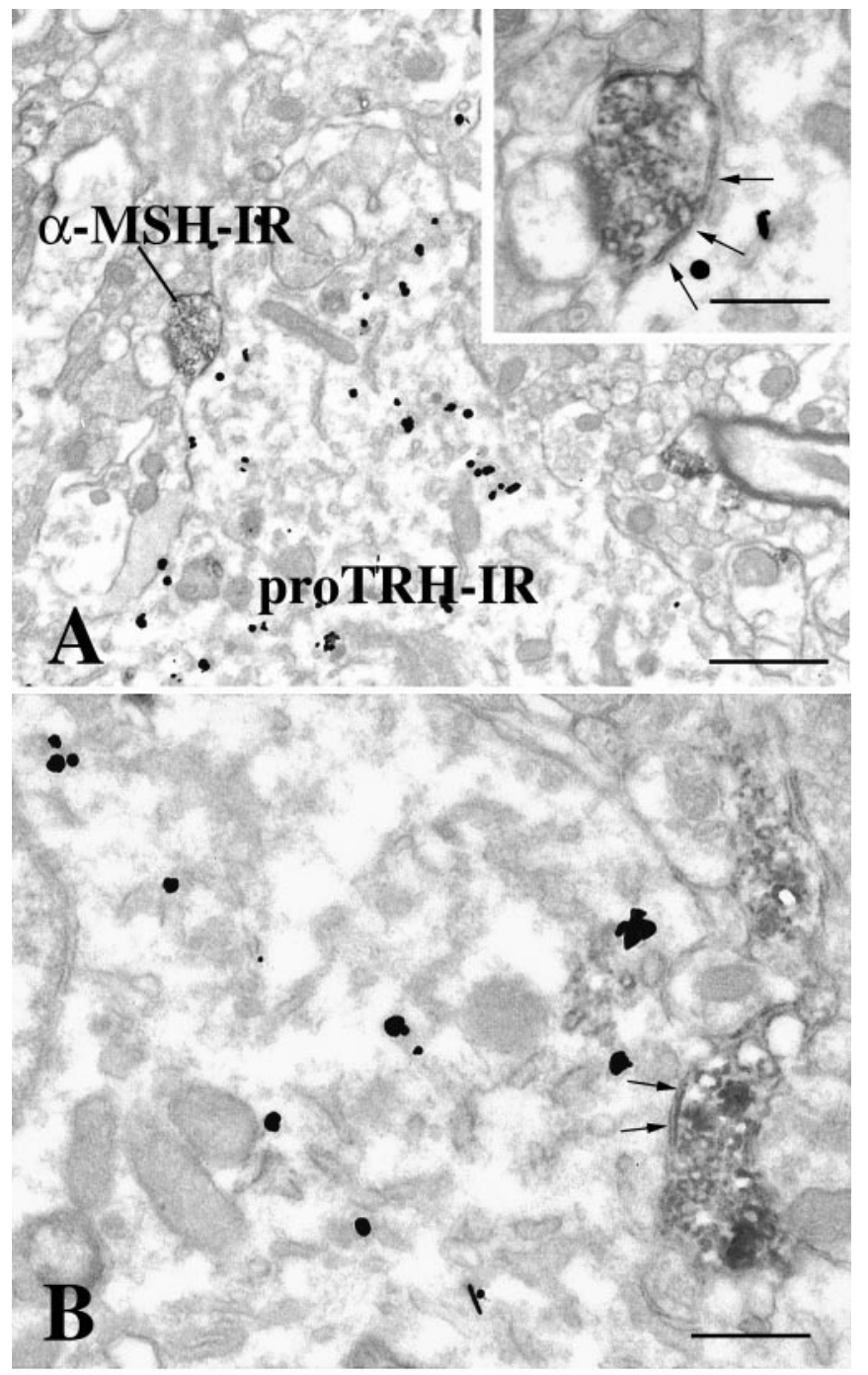

Figure 2. Electron micrographs showing synaptic associations (arrows) between pro-TRH-containing neurons in the PVN and $\alpha$-MSHcontaining axon terminals. The pro-TRH-IR dendrites and perikarya are labeled with highly electron-dense silver granules, whereas the $\alpha$-MSH-IR terminals are recognized by the presence of the electron-dense DAB. $A$, Medium-power magnification view of an axodendritic synapse, shown in greater detail in the inset. $B$, High-power magnification of an axosomatic synapse. Scale bars: $A, 1 \mu \mathrm{m} ; B$, inset, $0.4 \mu \mathrm{m}$.

and 38 and $52 \%$ of fed T4 and free T4 levels, respectively, but had no effect on the free T4 fraction. TSH values rose in the fasted animals receiving $300 \mathrm{ng}$ of $\alpha$-MSH, but the values were not significantly different from that of fed and fasted animals. Infusion of the lower dose of $\alpha$-MSH (150 ng) to fasted animals had no effects on any of the measured parameters compared with values in fasted control animals.

\section{Effect of fasting and $\alpha-M S H$ administration in fasting animals on pro-TRH mRNA in the PVN}

In fed animals, neurons containing pro-TRH mRNA were readily visualized by in situ hybridization histochemistry to be distributed symmetrically in the medial and periventricular parvocellular subdivisions of the PVN on either side of the third ventricle (Fig. 3A), whereas fasting caused a marked decrease in the hybridization signal over the paraventricular pro-TRH neurons (Fig. $3 B$ ). By image analysis, the sum of integrated density values of pro-TRH mRNA in the PVN of fasting animals was $44 \%$ of that of the fed animals (see Fig. $5 A$ ). In fasted animals receiving $300 \mathrm{ng}$ of $\alpha$-MSH every $6 \mathrm{hr}$, however, the hybridization pattern appeared identical to that of the fed controls (Fig. $3 D$ ), and the integrated density values were not significantly different from the fed levels (see Fig. 5A). No effect on the hybridization signal was induced by the lower dose of $\alpha$-MSH when compared with fasted animals receiving vehicle alone (see Figs. $3 C, 5 A$ ).

\section{Effect of fasting and $\alpha$-MSH administration in fasting animals on AGRP mRNA in the arcuate nucleus}

In fed animals, neurons containing AGRP mRNA were weakly visualized by in situ hybridization histochemistry in the arcuate nucleus (Fig. 4A). In contrast, silver grains densely accumulated over the AGRP neurons in fasted animals (Fig. 4B), were distributed in both medial and lateral portions of the arcuate nucleus, and increased by $740 \%$ compared with fed animals. Neither dose of $\alpha$-MSH to fasted animals significantly altered the integrated density values for AGRP mRNA compared with the fasted animals receiving vehicle, alone (Figs. $4 C, D, 5 B$ ).

\section{DISCUSSION}

These studies indicate that $\alpha$-MSH may have an important physiological role in the regulation of TRH-synthesizing neurons in the PVN. The presence of a dense network of $\alpha$-MSH-containing axons in the PVN that establish synaptic contacts both on the soma and first-order dendrites of pro-TRH-IR neurons provides an anatomical basis to propose a direct action of $\alpha-\mathrm{MSH}$ on these neurons. These data are consistent with previous light microscopic findings that $\mathrm{ACTH}$, also a post-translational cleavage product of POMC, is contained in axons adjacent to TRH neurons in the PVN (Liao et al., 1991). Although $\alpha-\mathrm{MSH}$ is synthesized in two regions within the brain, the arcuate nucleus and the nucleus tractus solitarius (Dube et al., 1978; Joseph et al., 1983), the arcuate nucleus is probably the only source of $\alpha$-MSHcontaining fibers in the PVN. Deafferentation of the mediobasal hypothalamus that separates the arcuate nucleus from the rest of the brain results in marked depletion of $\alpha$-MSH in the dorsal hypothalamus (Eskay et al., 1979), whereas nearly half of the POMC-synthesizing neurons in the arcuate nucleus are labeled by the retrograde transport of marker substances injected into the PVN (Sawchenko et al., 1982). Moreover, the POMC-containing fibers originating from the nucleus tractus solitarius are fine in appearance and lack varicosities, characteristically different from the tortuous fibers with numerous varicosities originating from the arcuate nucleus perikarya (Joseph and Michael, 1988) and observed to contact pro-TRH neurons. Thus, axons containing $\alpha$-MSH, like axons containing NPY and AGRP, may contribute to the arcuato-paraventricular pathway to innervate $\mathrm{TRH}$ neurons.

By double-labeling immunocytochemistry, pro-TRH neurons in the anterior and periventricular parvocellular subdivision of the PVN were observed to receive dual innervation by both $\alpha$-MSH and AGRP. The potential importance of this observation is implicit in the knowledge that both peptides bind melanocortin type 4 receptors (MC4-R) (Adan et al., 1994; Ollmann et al., 1997), which are expressed in parvocellular neurons in the PVN (Mountjoy et al., 1994), but have opposing actions. In cell lines that stably express the MC4-R, AGRP has a potent inhibitory action, blocking the generation of cAMP stimulated by $\alpha-\mathrm{MSH}$ (Ollmann et al., 1997). Similarly, in vivo, intracerebroventricular administration of $\alpha$-MSH substantially reduces food intake (Rossi 
Table 1. Thyroid hormone levels in fed, fasted animals and fasted animals receiving an intracerebroventricular infusion of $\alpha$-MSH at the designated dose every $6 \mathrm{hr}$ for $64 \mathrm{hr}$

\begin{tabular}{lcccr} 
& & & Fast $/ 150 \mathrm{ng}$ & \multicolumn{1}{c}{ Fast/300 ng } \\
& Fed & Fast & $\alpha$-MSH & \multicolumn{1}{c}{$\alpha$-MSH } \\
\hline T4 $(\mu \mathrm{g} / \mathrm{dl})$ & $5.8 \pm 0.70^{a}$ & $0.87 \pm 0.24^{b}$ & $1.16 \pm 0.39^{b}$ & $2.19 \pm 0.36^{a, b}$ \\
Free T4 fraction $(\%)$ & $0.018 \pm 0.001^{a}$ & $0.027 \pm 0.001^{b}$ & $0.027 \pm 0.001^{b}$ & $0.025 \pm 0.001^{b}$ \\
Free T4 $(\mathrm{pg} / \mathrm{ml})$ & $10.54 \pm 1.24^{a}$ & $2.18 \pm 0.5^{b}$ & $2.95 \pm 0.97^{b}$ & $5.48 \pm 0.92^{a, b}$ \\
TSH $(\mu \mathrm{U} / \mathrm{ml})$ & $33.9 \pm 2.9$ & $25.2 \pm 2.3$ & $26.3 \pm 5.7$ & $35.3 \pm 4.8$
\end{tabular}

Values are mean \pm SEM.

${ }^{a}$ Significantly different from Fast.

${ }^{b}$ Significantly different from Fed.

et al., 1998), whereas AGRP increases feeding, blocks the $\alpha$-MSH-induced reduction of food intake (Rossi et al., 1998), and, when overexpressed in transgenic mice, causes obesity (Ollmann et al., 1997). Therefore, the presence of $\alpha$-MSH- and AGRPcontaining axons converging on the same pro-TRH neurons in the PVN provides morphological evidence to suggest an interaction between melanocortin agonist and antagonistic effects, respectively, to regulate the transcription of pro-TRH mRNA.

Although all pro-TRH neurons in the PVN that received contacts by $\alpha$-MSH-containing axon terminals also received contacts by axons containing AGRP, the majority of pro-TRH neurons in the medial parvocellular subdivision of the PVN, where most of the hypophysiotropic TRH neurons reside (Ishikawa et al., 1988), were contacted by AGRP- but not $\alpha$-MSH-containing
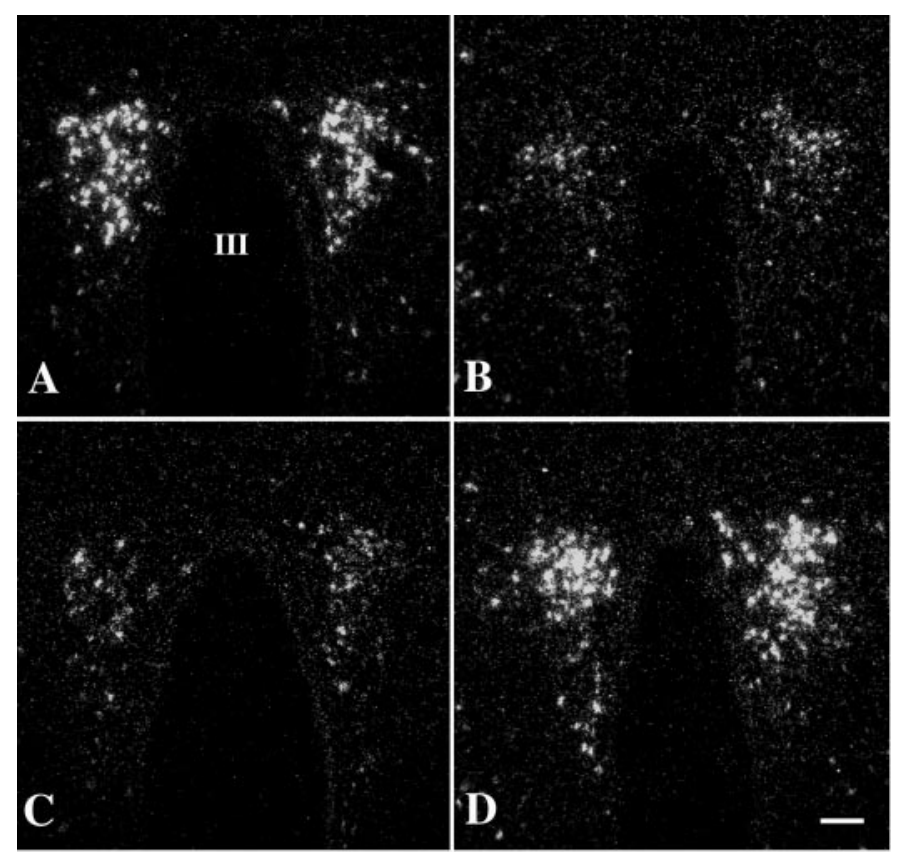

Figure 3. Dark-field illumination micrographs of pro-TRH mRNA in the medial and periventricular parvocellular subdivisions of the hypothalamic PVN in fed $(A)$ and fasted $(B)$ animals and fasted animals receiving an intracerebroventricular infusion of $\alpha$-MSH at a dose of $150 \mathrm{ng}(C)$ or 300 ng $(D)$ every $6 \mathrm{hr}$ for $64 \mathrm{hr}$. Note the reduction in the accumulation of silver grains over the PVN in fasted animals compared with the fed controls. Fasted animals receiving $150 \mathrm{ng}$ of $\alpha$-MSH every $6 \mathrm{hr}$ show suppression of pro-TRH mRNA in the PVN similar to that of fasted animals receiving artificial CSF. Fasted animals receiving $300 \mathrm{ng}$ of $\alpha$-MSH every $6 \mathrm{hr}$, however, show a marked increase in pro-TRH mRNA that is similar to that of fed control animals. III, Third ventricle. Scale bar, $100 \mu \mathrm{m}$. axon terminals. These observations raise the possibilities that AGRP may have actions on pro-TRH neurons independent of its antagonism of $\alpha$-MSH, either directly on the melanocortin receptor itself or through a separate receptor (Graham et al., 1997; Bures et al., 1998), and that only a subpopulation of hypophysiotropic pro-TRH neurons in the PVN is under direct control by $\alpha$-MSH. Nevertheless, whereas fasted animals receiving only vehicle intracerebroventricularly showed a significant reduction in pro-TRH mRNA in the PVN compared with fed controls, as reported previously (Blake et al., 1991; Legradi et al., 1997), the administration of $300 \mathrm{ng}$ of $\alpha$-MSH intracerebroventricularly every $6 \mathrm{hr}$ completely reversed the effect of fasting on pro-TRH gene expression, resulting in a hybridization pattern that was identical to that of the fed animals in all parvocellular subdivisions of the PVN. No selectivity for increased pro-TRH mRNA in periventricular parvocellular neurons was apparent. Similar observations have been reported by our group after the systemic administration of recombinant leptin to fasting animals (Legradi et al., 1997), suggesting that the increase in endogenous $\alpha$-MSH

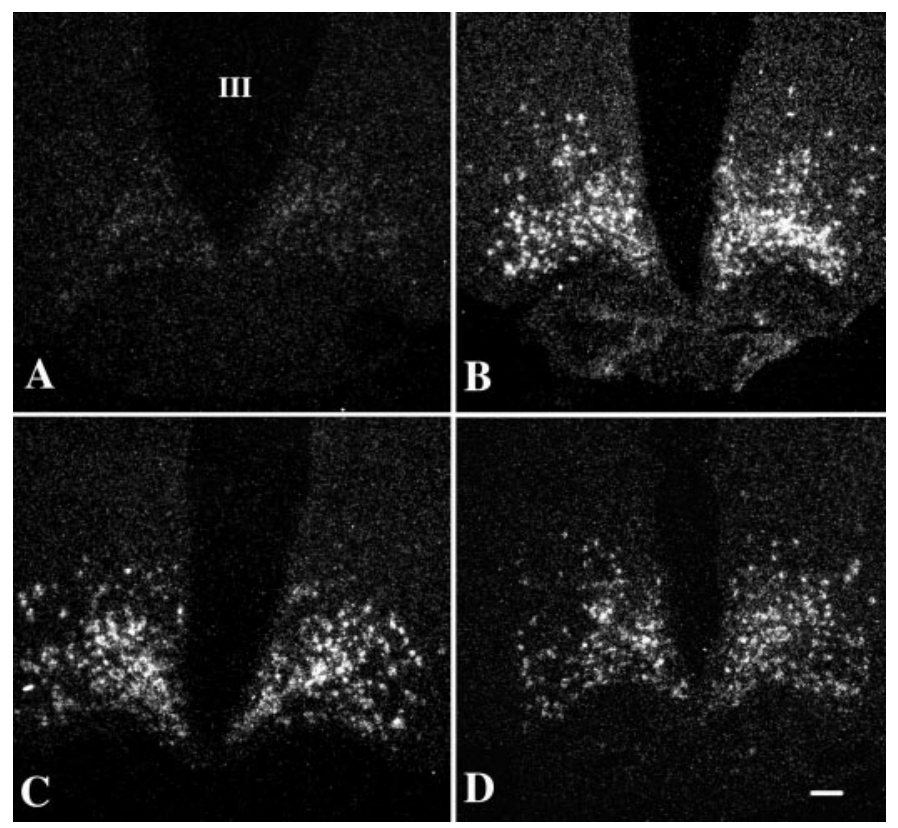

Figure 4. Dark-field illumination micrographs of AGRP mRNA in the arcuate nucleus of fed $(A)$ and fasted $(B)$ animals and fasted animals receiving an intracerebroventricular infusion of $\alpha$-MSH at a dose of 150 $\mathrm{ng}(C)$ or $300 \mathrm{ng}(D)$. Note the marked increase in AGRP mRNA in the fasted animals. No significant alteration in AGRP mRNA levels is apparent after $\alpha$-MSH administration in any of the groups. III, Third ventricle. Scale bar, $100 \mu \mathrm{m}$. 

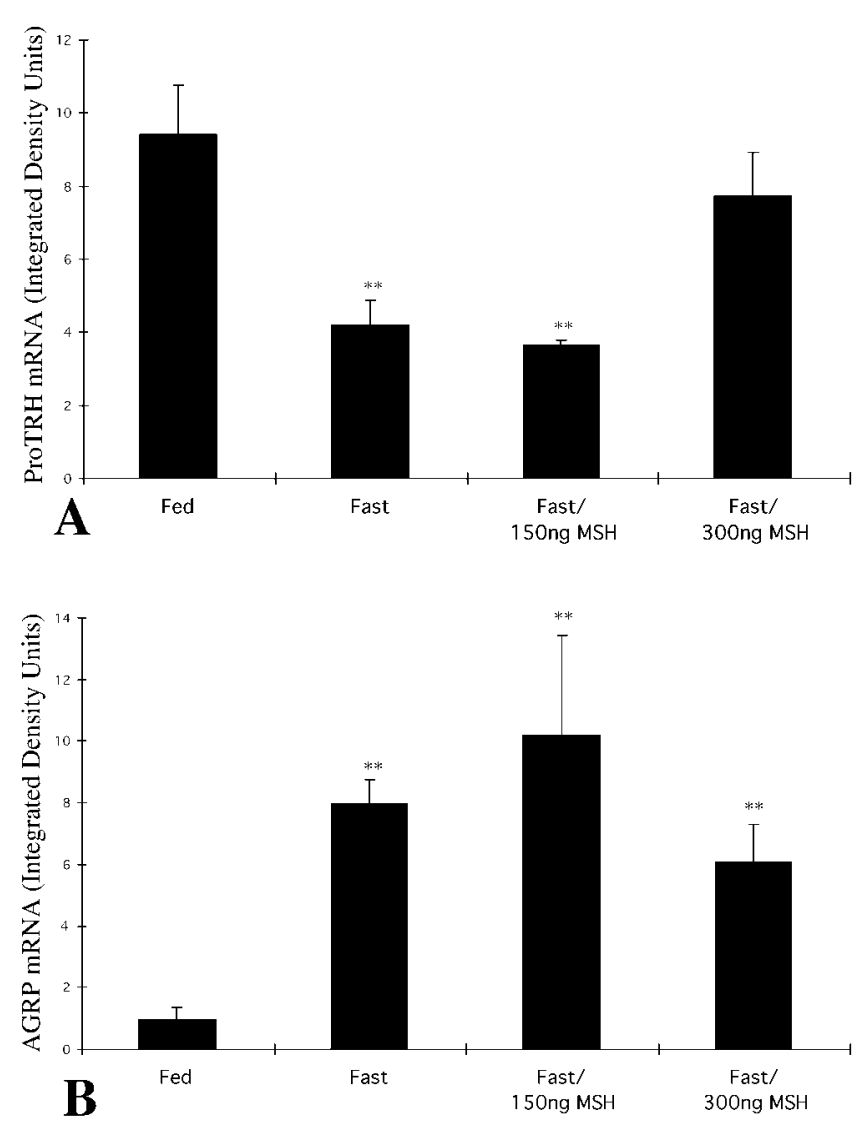

Figure 5. Computerized image analysis of pro-TRH mRNA content in the PVN $(A)$ and AGRP mRNA content in the arcuate nucleus $(B)$ of fed and fasted animals and fasted animals receiving an intracerebroventricular inf usion of $\alpha$-MSH at a dose of 150 or $300 \mathrm{ng}\left({ }^{* *} p<0.01\right.$ compared with fed animals).

associated with leptin-induced activation of POMC gene expression (Schwartz et al., 1997; Mizuno et al., 1998) may mediate the leptin-induced increase in pro-TRH mRNA in the PVN.

The anatomical selectivity of $\alpha$-MSH-containing axon terminals for pro-TRH neurons in the periventricular parvocellular subdivision of the PVN and the generalized effect of $\alpha$-MSH to increase pro-TRH gene expression in hypophysiotropic pro-TRH neurons, including medial parvocellular neurons, raise the possibility that $\alpha$-MSH may exert both direct and indirect effects on parvocellular neurons in the PVN. Along these lines, the hypothalamic dorsomedial nucleus (DMN) has well established projections to the parvocellular PVN (Ter Horst and Luiten, 1987; Thompson et al., 1996) and contains a subpopulation of neurons that are activated by the systemic administration of leptin (Elmquist et al., 1998). In addition, the DMN is one of the main targets for both $\alpha$-MSH- and AGRP-IR fibers (Jacobowitz and O'Donohue, 1978; Broberger et al., 1998), the latter originating exclusively from the arcuate nucleus (Broberger et al., 1998; Legradi and Lechan, 1999). Thus, the possibility of a leptinresponsive, multisynaptic pathway, composed of $\alpha$-MSH- and AGRP-producing neurons originating in the arcuate nucleus and influencing the activity of the PVN via afferents to the DMN, requires further study. Preliminary observations in our laboratory indicate that regions of the DMN send projections to the medial and periventricular parvocellular subdivisions of the PVN where they contact pro-TRH neurons (E. Mihály, C. Fekete, G. Légrádi, R. M. Lechan, unpublished observations).

In contrast to the $300 \mathrm{ng}$ dose of $\alpha-\mathrm{MSH}$, the lower $150 \mathrm{ng}$ dose did not affect pro-TRH mRNA in the PVN, which showed levels similar to that of the fasting controls. AGRP mRNA, however, was markedly increased by fasting, rising 8.4-fold over values in fed animals and not suppressed by either dose of $\alpha$-MSH. This differs from the effects of leptin to increase POMC gene expression (Schwartz et al., 1997; Mizuno et al., 1998) simultaneously with marked suppression of AGRP and NPY gene expression (Schwartz et al., 1996; Mizuno and Mobbs, 1999) when administered to fasting animals. Thus, in our studies, a certain threshold level of infused $\alpha$-MSH may have been required in the fasted animals to antagonize the inhibitory effects of the persistently elevated endogenous AGRP at the melanocortin receptor, before the stimulatory effects of exogenous $\alpha$-MSH on the TRH neurons in the PVN could be realized. In addition, the persistent elevation of AGRP mRNA in the $\alpha$-MSH-infused animals indicates that the effect of exogenous $\alpha$-MSH to increase pro-TRH mRNA in the PVN is not caused by inhibition of AGRP gene expression and that the fall in AGRP mRNA after leptin administration (Mizuno and Mobbs, 1999) is not mediated by a rise in $\alpha$-MSH. A negative short-feedback control system involving the regulation of AGRP gene expression by $\alpha$-MSH, therefore, probably does not occur in the arcuate nucleus.

Although the higher dose of $\alpha$-MSH was effective in completely restoring pro-TRH mRNA to fed levels in PVN neurons of fasting animals, plasma levels of thyroid hormone showed only a partial response, rising to $\sim 50 \%$ of fed levels. The rise in free T4 was greater than that observed for T4 because of the elevation of the free T4 fraction in all of the fasting groups, unaffected by $\alpha$-MSH infusion. These data are consistent with previous observations by our group that reduction in thyroid hormone-binding proteins in the peripheral circulation by tasting cannot be restored by leptin and thereby is probably not centrally mediated (Legradi et al., 1997). TSH did not significantly change in any of the four groups but was inappropriate for the level of T4 in fasting animals, suggesting reduction in its biological activity, likely because of changes in TRH released into the portal system (Taylor and Weintraub, 1989). Thus, in contrast to the effect of the systemic administration of leptin to fasting animals, which not only increases pro-TRH mRNA in the PVN but also fully restores thyroid hormone levels to normal (Legradi et al., 1997), $\alpha$-MSH appears to affect only part of the full regulatory effects of leptin on the thyroid axis, primarily via actions directed on the regulation of pro-TRH gene expression. Other factors that respond to leptin administration and act in coordination with $\alpha$-MSH downstream from the transcription of pro-TRH but are not affected by the intracerebroventricular administration of $\alpha$-MSH, alone, may also be necessary to achieve the full regulatory response of leptin on the thyroid axis. These factors may be peptides whose mRNA is known to be affected by leptin administration, such as NPY and AGRP in the arcuate nucleus and orexin and melanin-concentrating hormone in the lateral hypothalamus that are downregulated by leptin (Schwartz et al., 1996; Beck and Richy, 1999; Huang et al., 1999) and cocaine- and amphetamine-regulated transcript that is upregulated by leptin and also coexpressed in POMC neurons (Elias et al., 1998a; Kristensen et al., 1998).

We conclude that centrally administered $\alpha$-MSH exerts a potent stimulatory action on pro-TRH-producing neurons in the PVN, overriding the inhibitory effects of fasting. This effect may 
be mediated by a monosynaptic and/or multisynaptic pathway from the arcuate nucleus to hypophysiotropic TRH neurons. Thus, $\alpha$-MSH may have an important central role in the regulation of the thyroid axis and contribute to the mechanism by which leptin restores thyroid hormone levels to normal in fasting animals.

\section{REFERENCES}

Adan RA, Cone RD, Burbach JP, Gispen WH (1994) Differential effects of melanocortin peptides on neural melanocortin receptors. Mol Pharmacol 46:1182-1190.

Beck B, Richy S (1999) Hypothalamic hypocretin/orexin and neuropeptide Y: divergent interaction with energy depletion and leptin. Biochem Biophys Res Commun 258:119-122.

Blake NG, Eckland DJ, Foster OJ, Lightman SL (1991) Inhibition of hypothalamic thyrotropin-releasing hormone messenger ribonucleic acid during food deprivation. Endocrinology 129:2714-2718.

Branchereau P, Van Bockstaele EJ, Chan J, Pickel VM (1995) Ultrastructural characterization of neurons recorded intracellularly in vivo and injected with lucifer yellow: advantages of immunogold-silver vs. immunoperoxidase labeling. Microsc Res Tech 30:427-436.

Broberger C, Johansen J, Johansson C, Schalling M, Hokfelt T (1998) The neuropeptide Y/agouti gene-related protein (AGRP) brain circuitry in normal, anorectic, and monosodium glutamate-treated mice. Proc Natl Acad Sci USA 95:15043-15048.

Bures EJ, Hui JO, Young Y, Chow DT, Katta V, Rohde MF, Zeni L, Rosenfeld RD, Stark KL, Haniu M (1998) Determination of disulfide structure in agouti-related protein (AGRP) by stepwise reduction and alkylation. Biochemistry 37:12172-12177.

Castro MI, Alex S, Young RA, Braverman LE, Emerson CH (1986) Total and free serum thyroid hormone concentrations in fetal and adult pregnant and nonpregnant guinea pigs. Endocrinology 118:533-537.

Dube D, Lissitzky JC, Leclerc R, Pelletier G (1978) Localization of alpha-melanocyte-stimulating hormone in rat brain and pituitary. Endocrinology 102:1283-1291.

Dyess EM, Segerson TP, Liposits Z, Paull WK, Kaplan MM, Wu P, Jackson IM, Lechan RM (1988) Triiodothyronine exerts direct cellspecific regulation of thyrotropin-releasing hormone gene expression in the hypothalamic paraventricular nucleus. Endocrinology 123: 2291-2297.

Elias CF, Lee C, Kelly J, Aschkenasi C, Ahima RS, Couceyro PR, Kuhar MJ, Saper CB, Elmquist JK (1998a) Leptin activates hypothalamic CART neurons projecting to the spinal cord. Neuron 21:1375-1385.

Elias CF, Saper CB, Maratos-Flier E, Tritos NA, Lee C, Kelly J, Tatro JB, Hoffman GE, Ollmann MM, Barsh GS, Sakurai T, Yanagisawa M, Elmquist JK (1998b) Chemically defined projections linking the mediobasal hypothalamus and the lateral hypothalamic area. J Comp Neurol 402:442-459.

Elmquist JK, Ahima RS, Elias CF, Flier JS, Saper CB (1998) Leptin activates distinct projections from the dorsomedial and ventromedial hypothalamic nuclei. Proc Natl Acad Sci USA 95:741-746.

Eskay RL, Giraud P, Oliver C, Brown-Stein MJ (1979) Distribution of alpha-melanocyte-stimulating hormone in the rat brain: evidence that alpha-MSH-containing cells in the arcuate region send projections to extrahypothalamic areas. Brain Res 178:55-67.

Fan W, Boston BA, Kesterson RA, Hruby VJ, Cone RD (1997) Role of melanocortinergic neurons in feeding and the agouti obesity syndrome. Nature 385:165-168.

Graham A, Wakamatsu K, Hunt G, Ito S, Thody AJ (1997) Agouti protein inhibits the production of eumelanin and phaeomelanin in the presence and absence of alpha-melanocyte stimulating hormone. Pigment Cell Res 10:298-303.

Hakansson ML, Hulting AL, Meister B (1996) Expression of leptin receptor mRNA in the hypothalamic arcuate nucleus-relationship with NPY neurones. NeuroReport 7:3087-3092.

Huang Q, Viale A, Picard F, Nahon J, Richard D (1999) Effects of leptin on melanin-concentrating hormone expression in the brain of lean and obese lepob/lepob mice. Neuroendocrinology 69:145-153.

Huang XF, Koutcherov I, Lin S, Wang HQ, Storlien L (1996) Localization of leptin receptor mRNA expression in mouse brain. NeuroReport 7:2635-2638.

Ishikawa K, Taniguchi Y, Inoue K, Kurosumi K, Suzuki M (1988) Immunocytochemical delineation of thyrotrophic area: origin of thyrotropin-releasing hormone in the median eminence. Neuroendocrinology 47:384-388.

Jacobowitz DM, O'Donohue TL (1978) alpha-Melanocyte stimulating hormone: immunohistochemical identification and mapping in neurons of rat brain. Proc Natl Acad Sci USA 75:6300-6304.

Joseph SA, Michael GJ (1988) Efferent ACTH-IR opiocortin projections from nucleus tractus solitarius: a hypothalamic deafferentation study. Peptides 9:193-201.

Joseph SA, Pilcher WH, Bennett-Clarke C (1983) Immunocytochemical localization of ACTH perikarya in nucleus tractus solitarius: evidence for a second opiocortin neuronal system. Neurosci Lett 38:221-225.

Kakucska I, Rand W, Lechan RM (1992) Thyrotropin-releasing hormone gene expression in the hypothalamic paraventricular nucleus is dependent upon feedback regulation by both triiodothyronine and thyroxine. Endocrinology 130:2845-2850.

Koller KJ, Wolff RS, Warden MK, Zoeller RT (1987) Thyroid hormones regulate levels of thyrotropin-releasing-hormone mRNA in the paraventricular nucleus. Proc Natl Acad Sci USA 84:7329-7333.

Kristensen P, Judge ME, Thim L, Ribel U, Christjansen KN, Wulff BS, Clausen JT, Jensen PB, Madsen OD, Vrang N, Larsen PJ, Hastrup S (1998) Hypothalamic CART is a new anorectic peptide regulated by leptin. Nature 393:72-76.

Legradi G, Lechan RM (1998) The arcuate nucleus is the major source for neuropeptide Y-innervation of thyrotropin-releasing hormone neurons in the hypothalamic paraventricular nucleus. Endocrinology 139:3262-3270.

Legradi G, Lechan RM (1999) Agouti-related protein containing nerve terminals innervate thyrotropin-releasing hormone neurons in the hypothalamic paraventricular nucleus. Endocrinology 140:3643-3652.

Legradi G, Emerson CH, Ahima RS, Flier JS, Lechan RM (1997) Leptin prevents fasting-induced suppression of prothyrotropin-releasing hormone messenger ribonucleic acid in neurons of the hypothalamic paraventricular nucleus. Endocrinology 138:2569-2576.

Legradi G, Emerson CH, Ahima RS, Rand WM, Flier JS, Lechan RM (1998) Arcuate nucleus ablation prevents fasting-induced suppression of ProTRH mRNA in the hypothalamic paraventricular nucleus. Neuroendocrinology 68:89-97.

Liao N, Bulant M, Nicolas P, Vaudry H, Pelletier G (1991) Anatomical interactions of proopiomelanocortin (POMC)-related peptides, neuropeptide Y (NPY) and dopamine beta-hydroxylase (D beta $\mathrm{H}$ ) fibers and thyrotropin-releasing hormone (TRH) neurons in the paraventricular nucleus of rat hypothalamus. Neuropeptides 18:63-67.

Liposits Z, Sherman D, Phelix C, Paull WK (1986) A combined light and electron microscopic immunocytochemical method for the simultaneous localization of multiple tissue antigens. Tyrosine hydroxylase immunoreactive innervation of corticotropin releasing factor synthesizing neurons in the paraventricular nucleus of the rat. Histochemistry 85:95-106.

Mercer JG, Hoggard N, Williams LM, Lawrence CB, Hannah LT, Trayhurn P (1996) Localization of leptin receptor mRNA and the long form splice variant ( $\mathrm{Ob}-\mathrm{Rb})$ in mouse hypothalamus and adjacent brain regions by in situ hybridization. FEBS Lett 387:113-116.

Mizuno TM, Mobbs CV (1999) Hypothalamic agouti-related protein messenger ribonucleic acid is inhibited by leptin and stimulated by fasting. Endocrinology 140:814-817.

Mizuno TM, Kleopoulos SP, Bergen HT, Roberts JL, Priest CA, Mobbs CV (1998) Hypothalamic pro-opiomelanocortin mRNA is reduced by fasting and in ob/ob and $\mathrm{db} / \mathrm{db}$ mice, but is stimulated by leptin. Diabetes 47:294-297.

Mountjoy KG, Mortrud MT, Low MJ, Simerly RB, Cone RD (1994) Localization of the melanocortin-4 receptor (MC4-R) in neuroendocrine and autonomic control circuits in the brain. Mol Endocrinol 8:1298-1308.

Nillni EA (2000) Neuroregulation of proTRH biosynthesis and processing. Endocrinology, in press.

Ollmann MM, Wilson BD, Yang YK, Kerns JA, Chen Y, Gantz I, Barsh GS (1997) Antagonism of central melanocortin receptors in vitro and in vivo by agouti-related protein. Science 278:135-138.

Rondeel JM, Heide R, de Greef WJ, van Toor H, van Haasteren GA, Klootwijk W, Visser TJ (1992) Effect of starvation and subsequent refeeding on thyroid function and release of hypothalamic thyrotropinreleasing hormone. Neuroendocrinology 56:348-353.

Rossi M, Kim MS, Morgan DG, Small CJ, Edwards CM, Sunter D, Abusnana S, Goldstone AP, Russell SH, Stanley SA, Smith DM, Yagaloff K, Ghatei MA, Bloom SR (1998) A C-terminal fragment of 
Agouti-related protein increases feeding and antagonizes the effect of alpha-melanocyte stimulating hormone in vivo. Endocrinology 139:4428-4431.

Sawchenko PE, Swanson LW, Joseph SA (1982) The distribution and cells of origin of ACTH(1-39)-stained varicosities in the paraventricular and supraoptic nuclei. Brain Res 232:365-374.

Schwartz MW, Seeley RJ, Campfield LA, Burn P, Baskin DG (1996) Identification of targets of leptin action in rat hypothalamus. J Clin Invest 98:1101-1106.

Schwartz MW, Seeley RJ, Woods SC, Weigle DS, Campfield LA, Burn P, Baskin DG (1997) Leptin increases hypothalamic pro-opiomelanocortin mRNA expression in the rostral arcuate nucleus. Diabetes 46:2119-2123.

Segerson TP, Kauer J, Wolfe HC, Mobtaker H, Wu P, Jackson IM, Lechan RM (1987) Thyroid hormone regulates TRH biosynthesis in the paraventricular nucleus of the rat hypothalamus. Science 238:78-80.
Taylor T, Weintraub BD (1989) Altered thyrotropin (TSH) carbohydrate structures in hypothalamic hypothyroidism created by paraventricular nuclear lesions are corrected by in vivo TSH-releasing hormone administration. Endocrinology 125:2198-2203.

Ter Horst GJ, Luiten PG (1987) Phaseolus vulgaris leuco-agglutinin tracing of intrahypothalamic connections of the lateral, ventromedial, dorsomedial and paraventricular hypothalamic nuclei in the rat. Brain Res Bull 18:191-203.

Thompson RH, Canteras NS, Swanson LW (1996) Organization of projections from the dorsomedial nucleus of the hypothalamus: a PHA-L study in the rat. J Comp Neurol 376:143-173.

van Haasteren GAC, Linkels E, Klootwijk W, van Toor H, Rondeel JMM, Themmen APN, de Jong FH, Valentijn K, Vaudry H, Bauer K, Visser TJ, de Greef WJ (1995) Starvation-induced changes in the hypothalamic content of prothyrotrophin-releasing hormone (proTRH) mRNA and the hypothalamic release of proTRH-derived peptides: role of the adrenal gland. J Endocrinol 145:143-153. 